\title{
THE EPISTEMOLOGY OF SHARḤ HADITH IN AL-ANDALUS IN THE SECOND TO THE THIRD CENTURY AH: A BOOK STUDY OF TAFSÎR GHARÎB AL- MUWATṬA BY 'ABD AL-MALIK BIN ḤABÎB
}

\author{
Muhammad Akmaluddin \\ Universitas Islam Negeri Sunan Kalijaga Yogyakarta, Indonesia \\ muhammadakmaluddin@gmail.com \\ Article history: \\ Submitted: 03-07-2018 | Revised: 08-10-2018 | Accepted: 14-11-2018
}

\begin{abstract}
The fuqahâ' (Legal Scholars) and muhadditsûn (Hadith experts) have constructed the epistemology of Sharh Hadith in al-Andalus by its use and application. Interpreting Hadith by understanding the reality and context in al-Andalus provides a comparative understanding for society to better get the messages of the Hadith, rather than focus on its transmission and validity rules. Such approach is taken considering the situation and condition in al-Andalus demand the dissemination of practical knowledge, not theoretical knowledge as in Masyriq (the East) where the people have achieved deeper knowledge. The epistemology developed by 'Abd al-Malik bin Habîb (d. 238/852) in the second to the third century AH gives an illustration that Sharh Hadith is developed in its epistemic corridor. Basically, the study of Sharh Hadith in AlAndalus does not only have a passive role in the domination of Islamic centrist in the Masyriq, but also play an active role in interpreting various situations and conditions in the region. The relation of power between the Mâlik School and local knowledge in the epistemology of Sharh Hadith hadith are productive, producing practical and principle-based knowledge for the people in al-Andalus.
\end{abstract}

Keywords: Epistemology, Syarh Hadith, al-Andalus, Mâlik School

\begin{abstract}
Abstrak
Epistemologi syarh hadis di al-Andalus dibangun oleh para fuqahâ' dan muhadditsûn berdasarkan asas guna dan aplikasinya. Pemaknaan hadis dengan melihat realitas dan lokalitas di al-Andalus memberikan pemahaman yang komparatif sehingga masyarakat lebih memahami pesan-pesan hadis, daripada transmisi dan kaidah kesahihannya. Hal ini dilakukan karena situasi dan kondisi di al-Andalus yang menuntut penyebaran ilmu praktis, bukan teoretis seperti di Masyriq yang masyarakatnya sudah mencapai pengetahuan yang tinggi. Epistemologi yang dikembangkan oleh 'Abd al-Malik bin Habîb (w. 238/852) pada abad II - III H memberikan gambaran bahwa syarh hadis dikembangkan dalam ruang epistemiknya. Kajian syarh hadis di al-Andalus tidak hanya mempunyai peran yang pasif atas dominasi Islam sentris di Masyriq, tetapi juga mempunyai peran aktif dalam menerjemahkan berbagai situasi dan kondisi di al-
\end{abstract}


Andalus. Relasi kuasa mazhab Mâlik dan pengetahuan lokal dalam epistemologi syarh hadis sifatnya produktif, yaitu memproduksi pengetahuan yang praktis dan berdasarkan asas guna bagi masyarakat di al-Andalus.

Kata Kunci: Epistemologi, Syarḥ Hadis, al-Andalus, Mahzab Mâlik

\section{Introduction}

Al-Andalus is an area which is far from scientific civilization and has multiple ethnicities. It is sociologically the outermost area of Islam. Unlike some conquests in the Masyriq areas, Muslim conquerors did not demand the people in the area to convert to Islam or kill them. With multiple ethnicities, both from the indigenous people or Muslim conquerors, a multicultural interaction happened in al-Andalus. ${ }^{1}$ In addition, a series of wars between Muslims themselves due to the large number of ethnic groups in alAndalus in the second to the third century $\mathrm{AH}$ also took place. ${ }^{2}$ For this reason, this century is considered as a period of conquest and Islamic era in al-Andalus where the Islamic base in Masyriq experienced significant scientific progress. 'Âjil Husain shows the greatest time span of scientific codification in the regions around the Arabian Peninsula and al-Andalus is about 118 years, while the closest span is around 36 years. ${ }^{3}$

${ }^{1}$ Șâ'îd bin Ahmmad al-Andalusî, Kitâb Ṭabaqât al-Umam (Beirut: al-Maktabah al-Kâtsûlîkiyyah li al-Abâ' al-Yasû'iyyîn, 1912); Karîm 'Ajîl Husain, "al-Tamhîd li al-Tadwîn al-Târikhî fî alAndalus ḥattâ Nihâyah al-Qarn al-Tsânî al-Hijrî," Majallah Jâmi 'ah Tikrît li al-'Ulûm al-Insâniyyah 14, no. 11 (2007): 185-226.

${ }^{2}$ Roberto Marín-Guzmán, "La Rebelión Muladí En al-Andalus y Los Inicios de La Sublevación de 'Umar Ibn Hafsun En Las Épocas de Muhammad I y al-Mundhir (880-888)," Estudios de Asia y Africa 33, no. 2 (106) (1998): 233-284; Roberto MarínGuzmán, "Social and Ethnic Tensions in al-Andalus: Cases of Ishbîliyah (Sevilla) 276/889-302/914 and Ilbîrah (Elvira) 276/889-284/897- The Role of 'Umar Ibn Ḥafșūn," Islamic Studies 32, no. 3 (1993): 279-318; Roberto Marín-Guzmán, "The End of the Revolt of 'Umar Ibn Hafșūn in al-Andalus: The Period of 'Abd al-Raḥmân III (912-28)," Islamic Studies 34, no. 2 (1995): 153-205; Roberto Marín-Guzmán, "The revolt of 'Umar Ibn Hafsun in al-Andalus: A challenge to the structure of the state (880-928)" (Ph.D., 1994). \\uc0 $\backslash \backslash u 8221\{\}\{\backslash \backslash i\{\}$ Estudios de Asia y Africa\} 33, no. 2 (106

${ }^{3}$ Husain, "al-Tamhîd li al-Tadwîn al-Târikhî fî al-Andalus hattâ Nihâyah al-Qarn al-Tsânî al-Hijrî.” 192-194.
The development of a somewhat recent scientific study from other regions has not dampened the enthusiasm of the society and the Ulama of al-Andalus to develop science and civilization. There are six factors that has led to the development of science and civilization in al-Andalus, namely: 1) the migration of several companions as well as tabi'in (followers) and the conquerors to al-Andalus by transforming science and knowledge; 2) the coming of the ulama from Masyriq (the east) to al-Andalus; 3) the journey of al-Andalus people to Masyriq to study and then return to the region to disseminate their knowledge; 4) the collection of books and establishment of scientific and cultural centers such as mosques and libraries; 5) the love of the Umayyad rulers for knowledge in al-Andalus; and 6) the conflict of the Umayyad rulers against the Abbasids and Fathimiyyah in Masyriq. ${ }^{4}$

The dissemination of Islam in al-Andalus does not only result in a network of narration, but also studies, interpretation and scientific epistemology. The Muhadditsûn (Hadith experts) of al-Andalus, for example, allow almost all types of tahammul wa ad $\hat{a}$ ' (Hadith acquisition and delivery). This is different from the ulama in Masyriq who are very strict in this case, even with the Hadith pronunciation and use. ${ }^{5}$ The dominance of the Malik School colouring the scientific studies in alAndalus causes the study of Hadith to use as a tool to strengthen the school. ${ }^{6}$ They have only studied

\footnotetext{
${ }^{4}$ Husain Yûsuf Dwedâr, al-Mujtama' al-Andalusî fì al- 'Așr alUmawî (Kairo: Maṭba'ah al-Ḥusain al-Islâmiyyah, 1994), 383385.

${ }^{5}$ Muhammad Akmaluddin, "Developments of Hadîth Riwâya in al-Andalus (2nd - 3rd Centuries of Hijriyya)," Ulumuna 21, no. 2 (2017): 228-252.

${ }^{6}$ Ahmad Amîn, Zuhr al-Islâm, III (Kairo: Mu'assasah Hindâwî li al-Ta'lîm wa al-Tsaqâfah, 2012), 491.
} 
al-Qur'an and Muwaț̣a 'Mâlik (lâ na 'rif illâ kitâb Allâh wa Muwațta' Mâlik/we don't know anything except the Holy Quran and muwatta' Malik). ${ }^{7}$ In addition, the legal scholars (fuqahâ) of the Mâlik School have played a significant role in determining knowledge in al-Andalus. Here, they manipulate the opinions of the predecessors to build examples that better support the desired rules, primarily to support the legitimacy of the rulers. This is related to changes in the legal and political environment in al-Andalus so that the fatwa in this region is performed by the fuqahâ' ${ }^{8}$

In the meantime, the sharh Hadith in alAndalus is strongly influenced by the formality of isnâd (chains of narration) and Islamic law schools which distinguishes the classifications of the sharh Hadith in Masyriq. ${ }^{9}$ One of which is mentioned by Ibn 'Abd al-Barr (d. 463/1070) in his book, al-Tamhîd. ${ }^{10}$ The steps taken by Ibn Abd al-Barr have in turn found the chains of narration in the Hadiths consisting in Muwața 'Mâlik, which were initially disconnected. Four hadiths in this book in which Ibn' Abd al-Barr fails to find are then passed on by al-Ṣalâh (d. 643/1245). ${ }^{11}$ This means the hadiths in Muwatța 'Mâlik are all connected and have valid qualities as Șahị̂ al-Bukhârî and Șahîh Muslims. Therefore, it is not surprising that the scholars of al-Andalus have glorified the book and made it the only hadith

${ }^{7}$ Muḥammad bin Aḥmad al-Maqdisî, Ahsan al-Taqâsîm fî Ma 'rifah al-Aqâlîm (Kairo: Maṭba'ah al-Madbûlî, 1991), 236.

${ }^{8}$ Jocelyn Hendrickson, "Is al-Andalus Different? Continuity as Contested, Constructed, and Performed across Three Mâlikî Fatwâs," Islamic Law and Society 20, no. 4 (2013): 371-424.

${ }^{9}$ The commentators in al-Andalus call the Sharh Hadith as the interpretation of the hadith affected by their limited knowledge of the Holy Quran and Muwatta' Mâlik. In the Tafsir alMuwatța' by Yahyâ bin Ibrâhîm ibn Mazīn al-Qurțubî (d. 259 AH), for example, and Tafsìr Gharîb al-Muwatta' by 'Abd alMalik ibn Habîb al-Sulamî al-Ilbirî (d. 238 H). See Muhammad Akmaluddin, "Muhammad Akmaluddin, "Silsilah Riwâyah al-Ahâdîts Fî al-Andalus: Dirâsah Jîniyâlûjiyyah li Tațawwur Riwâyah al-Ahâdîts fî̀ al-Qarn al-Tsânî wa al-Tsâlits al-Hijrî “ (M.A., UIN Walisongo, 2015).

${ }^{10}$ Yûsuf bin 'Abd Allâh Ibn 'Abd al-Barr, al-Tamhîd li Mâ fî al-Muwațta' min al-Ma 'ânî wa al-Asânîd (Maroko: Wizârah 'Umûm al-Auqâf wa al-Syu'ûn al-Islâmiyyah, 1387).

11'Utsmân bin 'Abd al-Rahmân Ibn Șalâh al-Syahrazûrî, Waṣl Balâghât al-Muwatța', ed. 'Abd al-Fattâh Abû Ghuddah (Aleppo: al-Mațba'ah al-'Ilmiyyah, n.d.). book in al-Andalus at that time.

On the other hand,'Abd al-Malik bin Habîb (d. 238/852) applies a rather loose standard in tahammul wa adâ' to allow al-ijâzah and alwijâdah. ${ }^{12}$ Al-Qâdî 'Iyâḍ (d. 544/1149) has even identified a number of standard differences in the narration of the al-Andalus and Masyriq people in his book, al-Ilmâ ${ }^{6}{ }^{13}$ Identification of the hadith books in al-Andalus was carried out by Muhammad bin Jaefar al-Kattânî (d. 1345/1926). In his book entitled al-Risâlah al-Mustatrafah, he shows the study of the Hadith in al-Andalus focuses more on isnâd (chains of narration) which contradicts to the concept of the study of hadith in Masyriq. ${ }^{14}$

It is interesting to further learn the phenomenon of the study of hadith in al-Andalus. The study of regional hadith, especially in al-Andalus, is rarely performed in conferences or other academic scientific forums. 'Abd al-Razzâq Aswad, for example, mentions out of 60 hadith studies in the 1986-2004 period, there are only five regional studies or $8.3 \%$. The regional study also does not examine al-Andalus, but only a few regions such as Jordan, Morocco, Saudi Arabia, Tunisia and Algeria. ${ }^{15}$ In al-Andalus itself, the study of hadith was limited at the beginning of the second to the third century $\mathrm{AH}$ as it was a time to disseminate Islamic teachings and strengthen the conquered territories. Further, in the third century $\mathrm{AH}$, the study entered a new phase of the narration of hadith and continued with gradual periodization until the fifth century AH. Meanwhile, the

\footnotetext{
${ }^{12}$ Aḥmad bin Muhammad al-Maqqarî, Nafh al-Ṭ̂b min Ghusn alAndalus al-Rațîb wa Dzikr Wazîrihâ Lisân al-Dîn bin al-Khațîb, II, ed. Iḥsân 'Abbâs (Beirut: Dâr Ṣâdir, 1997), 8.

${ }^{13}$ Iyậ bin Mûsâ al-Yaḥ̦ubî, Al-Ilmâ' ilâ Ma'rifah Uș̂ul alRiwâyah wa Taqyîd al-Samâ', ed. Al-Sayyid A. Șaqar (Kairo: Dâr al-Turâts, 1970).

${ }^{14}$ Muhammad bin Ja'far al-Kattânî, al-Risâlah al-Mustatrafah li Bayân Masyhûr Kutub al-Sunnah al-Musyarrafah (Beirut: Dâr al-Kutub al-'Ilmiyyah, 2011); Akmaluddin, "Silsilah Riwâyah Al-Ahâdîts fî̀ al-Andalus: Dirâsah Jîniyâlûjiyyah li Tațawwur Riwâyah al-Ahâdîts fî̀ al-Qarn al-Tsânî wa al-Tsâlits al-Hijrî," 112-114.

${ }^{15}$ Muhammad 'Abd al-Razzâq Aswad, al-Ittijâhât al-Mu'âșirah fì Dirâsah al-Sunnah al-Nabawiyyah fi Mișr wa Bilâd Syâm (Damaskus: Dâr al-Kalim al-Ṭayyib, 2000), 150-156.
} 
narration period of the study of hadith and its variants happened in the fourth century $\mathrm{AH} .{ }^{16}$

The study, interpretation and epistemology of hadith which is different from Masyriq and the lack of studying and understanding hadiths in al-Andalus are the factors behind the writer to propose an epistemological study of sharh hadith in al-Andalus in the second to the third century AH. Such study refers to the two backgrounds; first, the epistemological study of Islam and the comparison between Maghrib (the West) and Masyriq (the East) has been carried out by al-Qâḍ̂ 'Iyâḍ; and secondly, the sharh hadith in al-Andalus has appeared earlier than other regions. The systematic sharh hadith, for example, was discovered in the fifth century in al-Mu 'lim bi Fawâ'id Muslim by Muhammad bin 'Alî bin' Umar al-Tamîmî al-Māzirî al-Mālikî (d. 536/1141). ${ }^{17}$ This article aims at illustrating the biography of 'Abd al-Malik bin Habîb alQurțubî (174/790-238/852) and the epistemology of sharh hadith in Tafsir Gharîb al-Muwatța' and analyzing it by the power and knowledge relation concept existing in al-Andalus.

\section{Biography 'Abd al-Malik bin Ḥabîb al- Qurțubî (174 / 790-238 / 852)}

'Abd al-Malik ibn Habîb bin Sulaimān alSulamî al-Ilbirî al-Qurțubî is the author of the early sharh hadith in al-Andalus. There was formerly a similar sharh to the Sharh Muwatta 'Mâlik written by Îsâ bin Dînār al-Ghâfiqî alQurțubî (d. 212/827). However, this work is mafqûd (physically undetected manuscripts, but its name is still in some books of tarâjim/ translated books or biographies of scholars). For

\footnotetext{
${ }^{16}$ Maribel Fierro, "The Introduction of Ḥadîth in al-Andalus (2nd/8th-3rd/9th Centuries)," Der Islam 66 (1989): 68-93; Maribel Fierro, "Local and Global in Hadîth Literature: The Case of a 1-Andalus," in The Transmission and Dynamics of the Textual Sources of Islam: Essays in Honour of Harald Motzki, ed. Nicolet Boekhoff-van der Voort, Kees Versteegh, and Joas Wagemakers (London: Brill, 2011), 63-88.

${ }^{17}$ Muhammad bin 'Alî bin 'Umar al-Tamîmî al-Mâzirî al-Mâlikî, al-Mu'lim bi Fawâ'id Muslim, ed. M. al-Syâdzâlî al-Nîfar (Tunis: al-Dâr al-Tûnisiyyah li an-Nasyr, 1988).
}

this reason, it cannot be used as an initial study in the epistemology of sharh hadith in al-Andalus. ${ }^{18}$

He narrated from 'ṣa'ṣa'ah bin Sallām, alGhāzî bin Qais and Ziyād bin 'Abd al-Raḥmân Syabțûn when he was in al-Andalus. Further, he has made an intellectual journey (rihlah' ilmiyyah) to Masyriq and narrated from 'Abd alMâlik bin al-Mâjisyûn, Muțarif ibn’ Abd Allâh, Ibrâhîm bin al-Munẓir al-Ḥizâmî, Aṣbagh bin al- Farj, Asad bin Mûsâ and others. In al-Andalus, he became a scholar and held a discussion with Yaḥyâ bin Yạ̣yâ al-Laitsi, Sa'īd bin Hassân and other Mâlikî School scholars. His students includes Muṭarrif bin Qais, Baqî bin Makhlad, Muḍdammad bin Waḍ̣ah, Yûsuf bin Yahyâ alMaghâmî and others. ${ }^{19}$

He is considered a controversial figure in the narration of his hadith. Ibn al-Faradị̂ (d. 403/1012) says that he did not have the knowledge of hadith, could not distinguish what was valid and not, and was too loose in narrating and using an ijazah (certification) in most of his narrations. ${ }^{20}$ Al-Dhahabî (d. 748/1347) in his Târîkh even mentions that he was accused of lying because he often related hadith without isnâd (chains of narration) and rawi (narrator) criticism. ${ }^{21}$

However, al-Maqqarî defends 'Abd al-Malik bin Habîb that such negative criticism could not be taken for granted. Many professional muhadditsûn (jahâbidzah) have narrated from him. In fact, there are many hadiths in which the source is not familiar for the most Masyriq such as al-Shifâ written by al-Qâdî 'Iyâḍ (d. 544/1149) and Musnad by Baqî bin Makhlad (d. 276/889) which are considered to consist of gharîb (unique)

\footnotetext{
${ }^{18}$ Abû Ya'lâ al-Baidâwî, al-Ta lîqât al-Mustazrifah 'alâ alRisâlah al-Mustațafah (Beirut: Dâr al-Kutub al-'Ilmiyyah, 2011); Akmaluddin, "Silsilah Riwâyah al-Ahâdîts fî al-Andalus: Dirâsah Jîniyâlûjiyyah li Tațawwur Riwâyah al-Ahâdîts fî alQarn al-Tsânî wa al-Tsâlits al-Hijrî,” 185.

19،Abd Allâh bin Muhammad Ibn al-Faraḍî, Târîkh 'Ulamâ' alAndalus, I, ed. Basysyâr 'Awwâd Ma'rûf (Tunis: Dâr al-Gharb al-Islâmî, 2008), 360.

${ }^{20}$ Ibid., 359-362.

${ }^{21}$ Muḥammad bin Aḥmad al-Dzahabî, Târîkh al-Islâm wa Wafayât al-Masyâhîr wa al-A lâm, V, ed. Basysyâr 'Awwâd Ma'rûf (Tunis: Dâr al-Gharb al-Islâmî, 2003), 876.
} 
hadiths. The transmission of the ijâzah narration model is permission for those who allow it. ${ }^{22}$

From some descriptions regarding the scientific capacity of 'Abd al-Malik bin Habîb, there are two aspects addressed to him; First, the assessment and negative criticism of his knowledge. Such assessment is based on the ideological and political conflict between him and Yahyâ bin Yahyyâ al-Laitsî (w. 234/848) and other fuqaha during the reign of Amir 'Abd al-Raḥmān al-Hakam (206/821-238/852). ${ }^{23}$ This political and ideological interests have eventually eliminated and have made him alienated from the fuqahâ community.

Second, his looseness in narrating with the ijazah (certification) model. This model, according to 'Abd al-Malik bin Habîb, happens for several reasons. At the beginning of the second to the third century HA, al-Andalus was an area that had not known much about Islamic studies, especially hadith. In addition, the population also did not really understand the importance of the written sources of hadith so that some early hadith books such as the one written by Mu'wiyah bin Șâlih al-Ḥimṣ̂ (d. 158/774) have disappeared. ${ }^{24}$ This kind of narration is tadrîj (gradual) in narrating and giving an understanding of the hadith to people who do not know it at all. The narration of book by ijâzah as assessed by

\footnotetext{
22al-Maqqarî, Naf̣̂ al-Tî̉b min Ghusn al-Andalus al-Rațîb wa Dzikr Wazîrihâ Lisân al-Dîn Bin al-Khațîb; Akmaluddin, "Developments of Hadîth Riwâya in al-Andalus (2nd - 3rd Centuries of Hijriyya)," 242-244.

${ }^{23}$ Jamâl 'Ilâl al-Bukhtî, "al-Madrasah al-'Aqdiyyah al-Ûlâ bi al-Andalus baina Ahl al-Fiqh wa Ahl al-Hadîts" (presented at the Buhûts al-Nadwah al-'Ilmiyyah al-Ûlâ al-Madrasah alHadîtsiyyah bi al-Maghrib wa al-Andalus: al-Imâm Ibn al-Qațân Namûdzajan, Markaz Ibn al-Qattân li al-Dirâsât wa al-Abhâts fi al-Hadîts al-Syarîf wa al-Sîrah al-'Ițrah, Maroko: al-Râbițah alMuhammadiyyah li al-'Ulamâ,' 2011), 161-205.

${ }^{24}$ Taufîq al-Ghalbazûrî, "Tațawwur 'Ilm al-Hadîts bi al-Maghrib wa al-Andalus ilâ al-'Așr al-Ḥaḍir wa Juhûd al-'Allâmah al-Muhaddits al-Duktûr Ibrâhîm Bin Șiddîq al-Ghumârî fî Khidmatihî" (presented at the Buhûts al-Nadwah al-'ilmiyyah al-Ûlâ al-Madrasah al-Hadîtsiyyah bi al-Maghrib wa al-Andalus: al-Imâm Ibn al-Qattân Namûdzajan, Markaz Ibn al-Qațân li alDirâsât wa al-Abhâts fi al-Hadîts al-Syarîf wa al-Sîrah al-'Ițrah, Maroko: al-Râbițah al-Muhammadiyyah li al-'Ulamâ,' 2011), $381-415$
}

Ibn al-Faraḍi only exists in the book written by Asad ibn Mûsâ or also knowns as 'Abd al-Malik bin Habîb. ${ }^{25}$

\section{Tafsir Gharîb al-Muwațta'}

Tafsir Gharîb al-Muwatța' is one of the books written by 'Abd al-Malik bin Habîb. His other writings include al-Wâdihah, al-Jāmi', Faḍ̂ 'il alhahâbah, Hurûb al-Islām, Faḍ̂́'il al-Masjidain, Sîrah al-Imām fî̀ Man Alhada, Tabaqât alFuqahâ', Raghâ'ib al-Qur'ân and Maṣâhîh $a l-H u d a .{ }^{26} \mathrm{He}$ lived where the al-Andalus people did many things forbidden by the religion such as interfaith marriage, the beliefs of local people and various prohibited heresies. Muslim identity was also eroded by Christians and Jews. Therefore, he also writes books containing threats, torture and punishment on the final day as written in his book, al-Ta'rikh and al-Ghâyah wa al-Nihâyah. ${ }^{27}$

This book which comments on on Muwatta' Mâlik is based on question and answer (dictaresponse) between 'Abd al-Malik bin Habîb and his student. Such comment is seen from the following sentence; "sa'alanâ 'Abd al-Malik bin Habîb (we asked 'Abd al-Malik bin Habîb) and answer "qâla 'Abd al-Malik bin Habîb ('Abd al-Malik bin Habîb said)". This book refers to kitâb waqût al-șalâh, asmâ' al-nabiyy șallâ Allâh 'alaihi wa sallam and jâmi 'al-jâmi'.

This book uses the history of Muwatța' Mâlik narrated by Yahyyâ bin Yahyâal-Laitsî, ‘Abd al-Malik bin Habîb's contemporary scholar. The unfavorable relationship between Yahyâ bin Yahyâ al-Laitsî and 'Abd al-Malik bin Habîb causes the book to design in the form of a question and answer system..$^{28}$ In this

\footnotetext{
${ }^{25}$ Ibn al-Faradî, Târîkh 'Ulamâ' al-Andalus. I: 360-361.

${ }^{26}$ Muhammad bin Ahmad al-Dzahabî, Siyar A'lâm al-Nubalâ', XII, ed. Syu'aib al-Arnâ'ûț (Beirut: Mu'assasah al-Risâlah, 1985), 103-104; Muștafâ bin 'Abd Allâh Hâjjjî Khalîfah, Kasyf al-Zunûn 'an Asâmî al-Kutub wa al-Funûn, I (Baghdad: Maktabah al-Mutsannâ, 1941), 909.

${ }^{27}$ Janina M. Safran, "Identity and Differentiation in NinthCentury al-Andalus," Speculum 76, no. 3 (2001): 573-598.

${ }^{28} \mathrm{See}$, for example, a number of different zindiq cases resolved between the fuqahâ' and muhadditsûn in Maribel Fierro, "Accusations of 'Zandaqa' in al-Andalus," Quaderni di Studi Arabi 5/6 (1987): 251-258.
} 
book, 'Abd al-Malik does not comment on all the words written in Muwatța' Mâlik, but only sentences that are considered difficult (musykil) or foreign (gharîb) both in pronunciation and meaning. ${ }^{29}$

This specialty of Tafsîr Gharîb al-Muwatta' is the first book to illustrate foreign sentences and commentaries on hadiths written in al-Andalus. ${ }^{30}$ In addition, it also describes almost all the books or chapters in Muwatța 'Mâlik. By using easyto-understand sentences and various narrations, it presents how contradictory texts are resolved and interpreted. Some hadiths by al-Qâdî 'Iyâd which are classified as popular foreign (gharib) hadiths, for example, also appear in al-Andalus and are unknown to the Masyriq scholars. ${ }^{31}$

Al-Fațh bin Muhammad al-Qaisî mentions the book written by 'Abd al-Malik bin Habî̉ consists of various fields of disciplines such as hadith, fiqh, linguistics and syntax and poetry. ${ }^{32}$

In the meantime, al-Maqqarî states that Tafsir Gharîb al-Muwatța is a book compiled based on hadith and obtained from Mâlik's senior students, even 'Abd al-Malik bin Habîb himself had learned to Mâlik. ${ }^{33}$

The shortcomings of the book include failing to explain the validity status of the hadiths and presenting too many comments. Some of the hadiths used in the commentary by 'Abd al-Malik bin Habîb are considered to disregard the criteria for the validity of the hadiths. Ibn al-Faradî, for example, says the quality of the hadiths by 'Abd al-Malik bin Habîb is in the flexible category and receives many models of ijazah (certification). ${ }^{34}$

29'Abd al-Malik bin Ḥabîb bin Sulaimân al-Sulamî, "alMuqaddimah," in Tafsîr Gharîb al-Muwațta', ed. "Abd alRaḥmân bin Sulaimân al-'Utsaimîn (Riyadh: Maktabah al'Abîkân, 2001), 9-167.

${ }^{30}$ Akmaluddin, "Silsilah Riwâyah al-Ahâdîts Fî al-Andalus: Dirâsah Jîniyâlūjiyyah Li Tațawwur Riwâyah al-Ahâdîts Fî alQarn al-Tsânî Wa al-Tsâlits al-Hijrî,” 185.

${ }^{31}$ al-Maqqarî, Nafh Al-Tî̉b Min Ghusn al-Andalus al-Rațîb Wa Dzikr Wazîrihâ Lisân al-Dîn Bin al-Khațîb, II: 8.

${ }^{32}$ al-Fath bin Muhammad al-Qaisî al-Isybîlî, Matmah al-Anfus Wa Masrah al-Ta'annus Fi Milh Ahl al-Andalus, ed. Muhammad 'Alî Syawâbikah (Dâr 'Ammâr: Mu'assasah al-Risâlah, 1983), 235.

${ }^{33}$ al-Maqqarî, Nafh al-Tî̉b Min Ghusn al-Andalus al-Rațîb Wa Dzikr Wazîrihâ Lisân al-Dîn Bin al-Khațîb, II: 6-7.

${ }^{34}$ Ibn al-Faradî, Târîkh 'Ulamâ' al-Andalus, I: 360.
The absence of a complete sanad (chains of narration) of hadith and rawi (narrator) criticism in the book causes 'Abd al-Malik bin Habîb to be considered as a disseminator of false hadith by al-Dhahabî. ${ }^{35}$ However, such criticism is too generic so it needs to be further proven to what extent the accusation is.

In addition to the shortcomings, some of the contents in the book tend to be biased against some ideological, political and theological issues. Thus, the reader must be careful of the comments of such hadits. ${ }^{36}$

\section{The Epistemology of Sharh Hadith in Tafsir Gharîb al-Muwațța'}

Epistemology or the theory of knowledge has material objects in the form of knowledge and formal objects in term of the essence of knowledge. ${ }^{37}$ According to al-Jābirî, epistemology derives from the thinking of an area has different features and characteristics compared to other regions. In this case, such thinking is the thinking of al-Andalus (al-fikr al-Andalusî) which is a set of opinions and thoughts used by the al-Andalus scholars on various issues and concerns regarding certain ideologies such as morals, beliefs, schools, politics, socio and also views of humans and nature. ${ }^{38}$ This thinking is not merely a content (al-fikr al-muhtawâ), but also as an instrument (al-fikr al-muhtah) which produces reasons, both ideologically and scientifically. ${ }^{39}$ Here, instruments are defined as a set of principles,

\footnotetext{
${ }^{35}$ al-Dzahabî, Târîkh al-Islâm Wa Wafayât al-Masyâhîr Wa alA 'Lâm, V: 876.

${ }^{36} \mathrm{~A}$ discussion concerning this case will be further studied in the next analysis.

${ }^{37}$ Rizal Mustansyir and Misnal Munir, Filsafat Ilmu (Yogyakarta: Pustaka Pelajar, 2015), 16-17.

${ }^{38}$ Thinking in this sense excludes knowledge that is not related to any ideology, including scientific knowledge, both theoretical and applicable knowledge. See Muhammad 'Âbid al-Jâbirî, Isykâliyyât al-Fikr al- 'Arabî al-Mu 'âșir (Beirut: Markaz Dirâsât al-Wahdah al-'Arabiyyah, 1990), 51.

${ }^{39} \mathrm{As}$ for thinking as content (al-fikr al-madmûn), it is defined as imagination formation, both in the form of views, thoughts and theories. According to al-Jābirî, Arabic thought is defined as content and instruments, or ideological and logical formations (bunyah îdiyûlûjiyâ wa bunyah 'aqliyyah), Ibid., 53.
} 
concepts and mechanisms that govern and take root in a person from childhood. This set of principles, concepts and mechanisms is not natural, but obtained by humans as an influence of interacting with their environment; natural, social and cultural environments. ${ }^{40}$

The thinking of al-Andalus is a description, opinion or theory that reflects the reality of alAndalus, and is even considered as an influence of reasoning methods or styles that contribute to the formation of some information on the reality of al-Andalus. ${ }^{41}$ This thinking and environmental relation will, according to al-Jābirî, form a system of knowledge in a society. The absence or existence of innovation (ibdâ $\hat{a}^{6}$ ) is determined by the relation, in terms of art, philosophy and scientific knowledge. In epistemic areas such as art, philosophy and science, ibdâ' is defined as the creation of a new thing coming from certain types in interactions with other or old types. Such interaction may be the term of developing, rearranging or denying and passing the thing. ${ }^{42}$

The innovation of knowledge is related to two things, al-jaddah (novelty) and al-aṣalah (originality). What differs innovation in the field of scientific knowledge (haql al-ma 'rifah al'ilmiyyah) is discovery (iktisyâf) and verifiable (qäbil li al-tahaqquq) in which both become the basis of an innovation. According to alJābirî, al-jaddah in art and philosophy is the same as iktisyâf, while al-asâlah is similar to qābil li al-tahaqquq, empirically, logically and experimentally. ${ }^{43}$ In the study of sharh hadiths carried out by 'Abd al-Malik bin Habîb, there are several innovations of knowledge which are not found in the comments of other hadith books in term of the factors of language, locality, history and others.

In the Tafsīr Gharīb al-Muwatta', 'Abd alMalik bin Habîb does not give all commentaries

\footnotetext{
${ }^{40}$ Ibid., 53.

${ }^{41}$ Ibid., 52 .

${ }^{42}$ Ibid., 53.

${ }^{43}$ Ibid.. 54
}

(sharh) to all the hadiths or sentences in alMuwatta'. He emphasizes the gharîb (foreign) sentence according to the al-Andalus people in an interactive-dialogical way with the questioners. The following hadith is the example: ${ }^{44}$

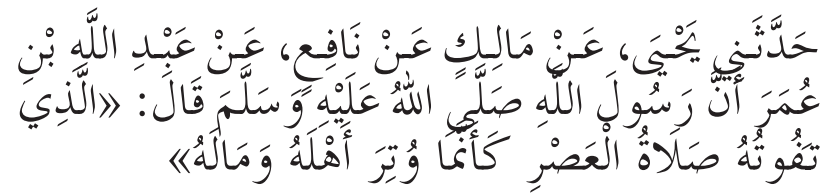

Meaning: Yahyâ has narrated to me, from Mâlik, from Nâfi, from 'Abd Allâh ibn 'Umar stating that the Messenger of Allāh (Prophet Muhammad) said: "Someone who misses performing Asr prayer is like a person who sacrifices his family and property."

'Abd al-Malik bin Habîb in the Tafsīr Gharîb al-Muwatta' is asked by several people regarding the above hadith as explained in the following: ${ }^{45}$

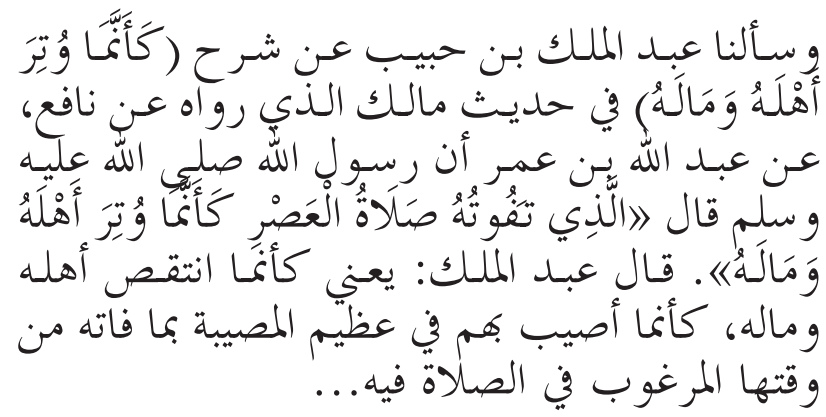

Meaning: We asked 'Abd al-Malik bin Habîb about the commentary of hadith ka'annamâ wutira ahlahû wa mâlahû (like a person who sacrifices his family and property) in the hadith narrated from Nâfi' from 'Abd Allâh bin 'Umar that the Messenger of Allah said: Someone who misses performing Asr prayer is like a person who 'sacrifices' his family and property. 'Abd al-Malik argued: The meaning of the sacrifice in the hadith is that as if one's

\footnotetext{
${ }^{44}$ Mâlik bin Anas al-Aṣbâhî, Muwațtâ' al-Imâm Mâlik, ed. Muhammad Fu'âd 'Abd al-Bâqî (Beirut: Dâr Ihyâa' al-Turâts al'Arabî, 1985), 11-12.

45، Abd al-Malik bin Habîb bin Sulaimân al-Sulamî, Tafsîr Gharîb al-Muwatța', I, ed. 'Abd al-Raḥmân bin Sulaimân al-'Utsaimîn (Riyadh: Maktabah al-‘Abîkân, 2001), 182-183.
} 
family and property is away. His family seems to be hit by a great disaster because the person has left the prayer... ".

The study of sharh hadith in al-Andalus has several methods which are somewhat different from the one in Masyriq. Muwatța', for example, is the main and mandatory reference in the study of hadith in al-Andalus. In addition, it is a book which is systematically codified based on the chapter of fiqh and becomes the only hadith book used in the second to the third century AH. Therefore, sharh hadith is only intended for Muwaț̣a' Mâlik. There are about eight sets of sharh Muwaha' Mâlik in al-Andalus in the third century $\mathrm{AH}^{46}$

Basically, 'Abd al-Malik bin Habîb has quoted many comments from his teacher like Așbagh bin al-Farj in commenting the hadith and Asad bin Mûsâ. This quote is seen in the etymological aspects of sentences in the hadiths and other ulama followers of Mâlik bin Anas (d. 179/795) when he was in Medina. He has also allegedly taken a lot of Gharîb al-Hadîts by al-Qasim ibn Sallam al-Harawî al-Baghdadi (d. 224/838). ${ }^{47}$

In dealing with contradictory hadiths ( $t a$ 'âruḍ), 'Abd al-Malik bin Habîb applies several methods. The first is ta'wîl, which is an explanation of several hadiths that contradict to the existing context. Here is the example: ${ }^{48}$

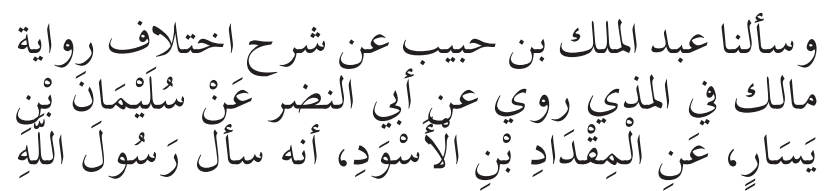

\footnotetext{
${ }^{46}$ Akmaluddin, "Silsilah Riwâyah al-Ahââits fî̀ al-Andalus: Dirâsah Jîniyâlûjiyyah li Tațawwur Riwâyah al-Ahâdîts fî alQarn al-Tsânî wa al-Tsâlits al-Hijrî," 185-186.

${ }^{47}$ 'Abd al-Malik bin Habîb has taken a lot from al-Qasim bin Sallam without clearly mentioning the source, even though both lived in the same era. 'Abd al-Raḥmân bin Sulaimân al'Utsaimîn, the editor of this book, suspects that there is no direct meeting (liq $\left.\hat{a}^{\prime}\right)$ and the absence of narration by Abd alMalik bin Ḥabîb from Qâsim bin Sallâm has forced him to miss explaining the references. This is because liqa and narration were not possible at the time. See the footnotes in al-Sulamî, Tafsir Gharîb al-Muwatta', I: 174-176. However, this equation does not mean 'Abd al-Malik bin Habîb has taken directly from al-Qasim bin Sallam, but only with a critical note.
}

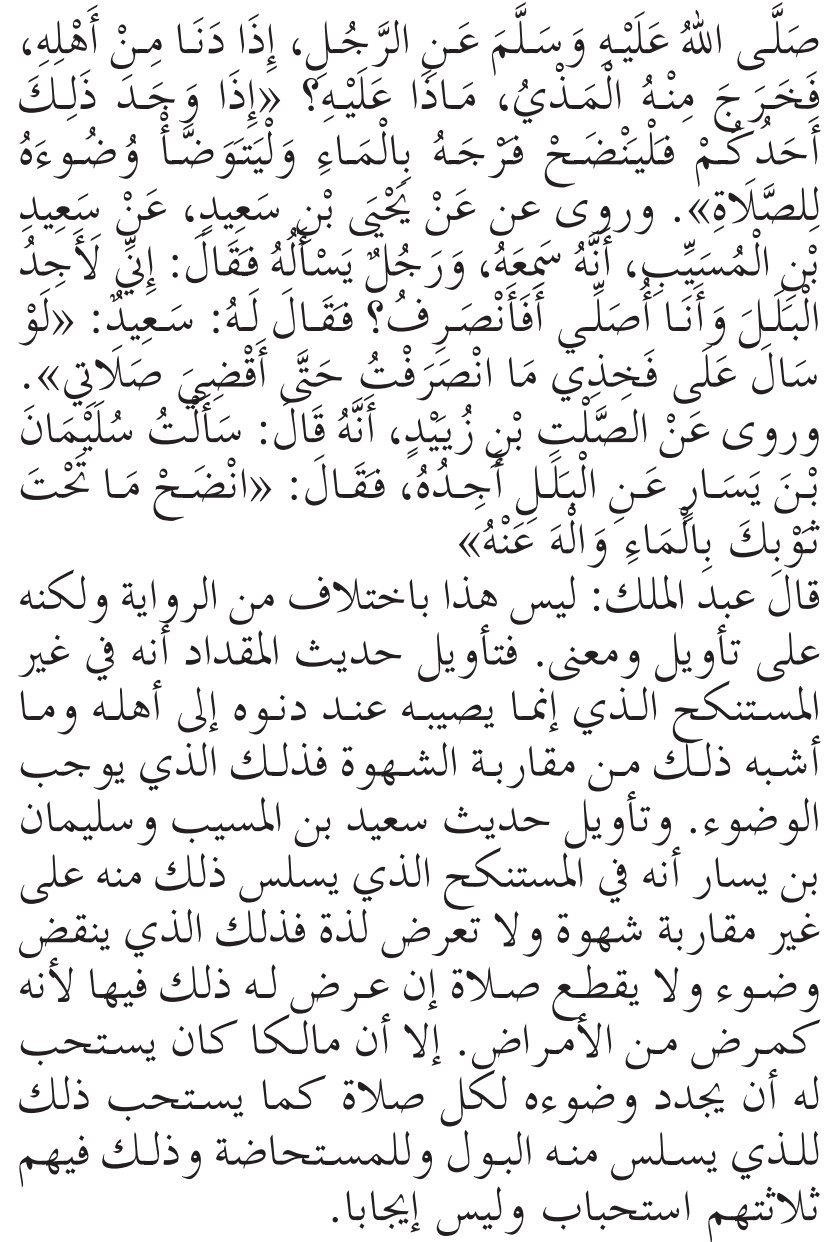

Meaning: We asked 'Abd al-Malik bin Habîb about Malik's comment on the difference between his narration in terms of madzi (precum) narrated from Abû al-Naḍ, from Sulaiman bin Yasr, from al-Miqdad ibn alAswad that he actually asked the Messenger of Allah about someone who approaches his wife and gets precum, what should the person do then? The Messenger said. "If one of you encounters this, then wash the genitals with water and perform ablution (wudhu') for praying purpose." Another narration from Yahyâ bin Sa'îd, from Sa 'îd bin al-Musayyab that someone asked the Messenger of Allah: "I found my genital wet while I was in a state of performing a prayer. Do I have to turn away?" Sa' $\mathrm{i} d$ answered: "If a wet thing is flowing in my thigh, then I will not turn away until I finish the prayer." The narration from al-Salt bin Zubaid mentions: "I asked 
Sulaiman bin Yasar about the wet thing I encountered, he replied: "Clean what is under your shirt with water and get rid of it".

'Abd al-Malik bin Habîb said: "This (problem) does not contradict to the narration, but must be interpreted according to the takwil and meaning. Takwil hadith al-Miqdâd, for example, is intended for those who are not married and get precum (madzi) when approaching the family or others due to the impulse of lust. Therefore, he is obligated to perform ablution (wudu'). Regarding the takwil of hadith by Sa'id bin al-Musayyab and Sulaimān bin Yasâr, it is addressed to married people who experience some kind of enuresis (inability to control madzîl precum) without lust and pleasure. This nullifies ablution (wudhu'), but does not nullify prayer as it is considered like other illnesses. However, Mâlik recommends redoing the ablution if they are willing to perform prayer as recommended to those who suffer from urinary and mustahâhah enuresis. The redoing of ablution for these three people (madzi enuresis, urination and mustahâdah) is sunnah, not obligatory."

Second, referring to the status of the hadith, whether it is specifically addressed to Prophet Muhammad or not. The specificity of an act by the Prophet does not apply to people afterwards. Similarly, you must see the hadith which is khâș (special) or âmm (general) and nâsikh (the abrogator) or mansûkh (the abrogated). See the following example. ${ }^{49}$

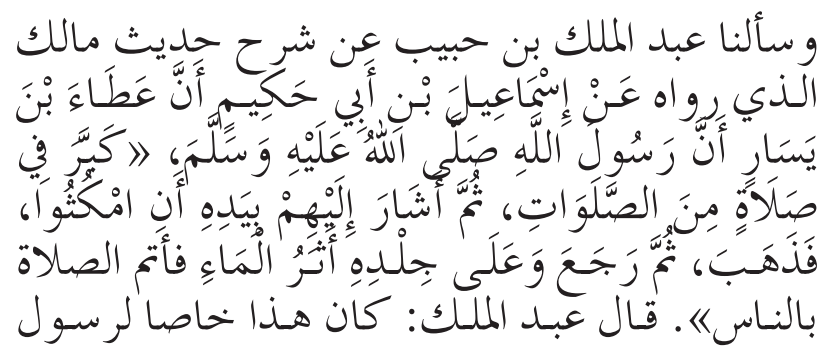

${ }^{49}$ Ibid., I: 203.
الله صلى الله عليه و سلم وليس بجائز لغيره و وذا من إنه

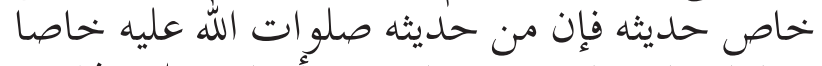

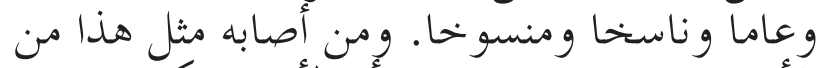

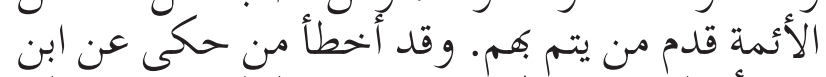

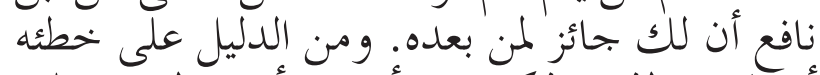

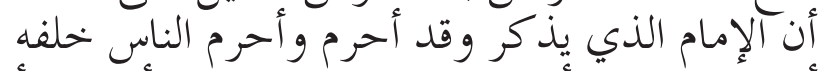

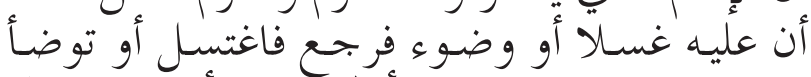

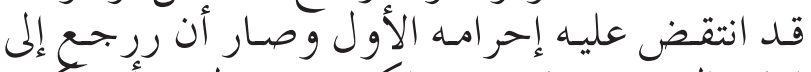

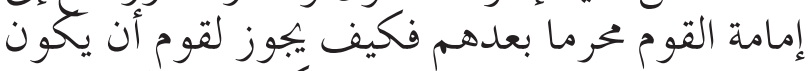

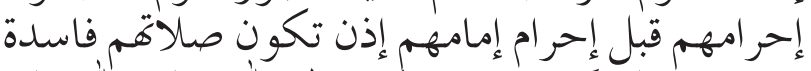

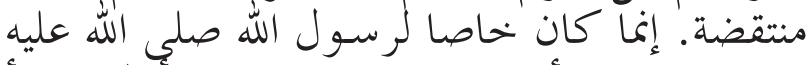

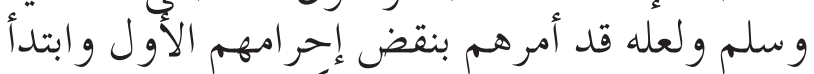

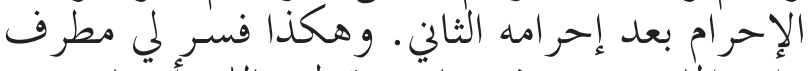

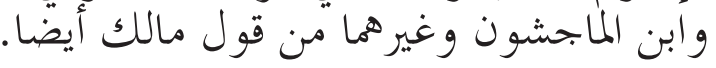

Meaning: We asked 'Abd al-Malik bin Habîb about Mâlik's comment on the hadith narrated from Ismâ'îl bin Abî Hakîm, from 'Aṭ̂a 'ibn Yasâr stating that the Messenger of Allāh (Prophet Muhammad) performed takbir in one of the prayers and then signaled with his hand so that all worshipers remained in place. He went out and when he returned, there was a trace of water on his skin and then completed his prayer. 'Abd al-Malik replied: "This act is specifically addressed to the Prophet and others are not allowed to follow him, and this hadith is one of his specialties. The hadith from the Prophet are classified to khâșs, 'âm, nâsikh and mansukh. If an imam does something as done by the Prophet, then there must be someone who replaces him to complete the prayer. The person who has narrated from Nâfi saying that it is permissible to follow the Prophet's act is wrong. This means if an imam remembers, but he has already performed takbiratul ihram with followers (makmum) behind him, that he forgets taking a shower or performing ablution then he turn around to take a shower or ablution, the first takbiratul ihram is then nullified. He must be replaced by the one behind him. Therefore, it is not permissible for a Muslim to do takbiratul ihram before 
the imam. If so, his prayer is then nullified. The aforementioned Hadith is devoted to the Prophet and he may have told his followers to cancel the first takbiratul ihram and start doing takbiratul ihram after the second takbir. This is as interpreted to me by Mutarrif, Ibn al-Mâjisyûn and others from Mâlik's opinion as well."

The third applies nâsikh-mansûkh, ${ }^{50}$ and the fourth uses tarjîh on the opinion of Mâlikiyyah scholars based on the tradition of the Madinah society. ${ }^{51}$ The step is taken considering that Medina was the place where companions who followed the Prophet and the followers of Mâlik lived, so that any religious deeds and practices continued from the time of the Prophet until their time. ${ }^{52}$ In addition, Medina was a place of migration for Muslims and their faith as mentioned in several hadiths. ${ }^{53}$

The method of sharh hadith carried out by 'Abd al-Malik bin Habîb is as follows:

a) Explaining The Hadith Sentences With The Qur'an

'Abd al-Malik bin Habîb uses the verses of the Qur' an to interpret and explain the meaning of the hadith sentences. The following is the example: ${ }^{54}$

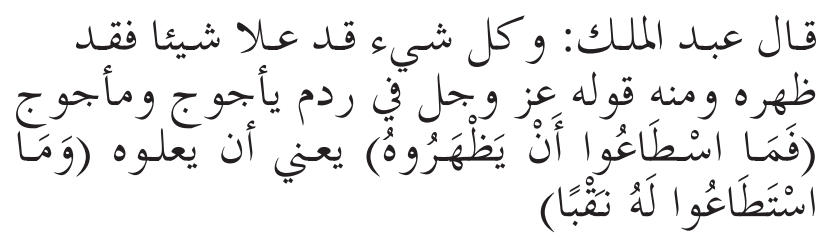

Meaning: "'Abd al-Malik bin Habîb said: "Everything which is higher than something else will reveal itself. The word of Allah concerning the detention of $Y a{ }^{\prime} j \hat{j} j$ and $M a$ 'jûj is the example; Then they cannot climb it,

\footnotetext{
${ }^{50}$ Ibid., I: 236.

${ }^{51}$ Ibid., I: 243 and 260.

${ }^{52}$ Ibid., II: 20.

${ }^{53}$ Ibid., II: 221-22.

${ }^{54}$ Ibid., I: 173.
}

which is to reach it and they cannot (also) perforate it."

b) Explaining The Hadith Sentences With Other Hadiths

As interpreting the Holy Qur'an, 'Abd alMalik bin Habîb applies many other hadiths to interpret and explain the meaning of a hadith sentence. He also carries out this approach when contradictions or understandings that require sabab wurûd from other hadits happen. See the following example: ${ }^{55}$

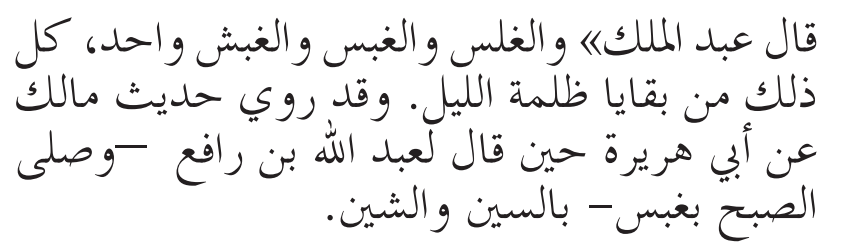

Meaning: 'Abd al-Malik bin Habîb said, "Al-ghalas, al-ghabas and al-ghabasy have similar menaing, which means the rest of the darkness of night. Mâlik has narrated from Abû Hurairah when he said to 'Abd Allāh ibn Näfi: "And the Messenger of Allah performed the Prayer during the Ghabas (the rest of the darkness of night)."

c) Explaining The Hadith Sentences With Sharh Hadith of Other Books

In this case, 'Abd al-Malik bin Habîb has quoted many explanations from Gharîb al-Hadîts by al-Qāsim bin Sallām (syârîh al-Syâmiyyîn) with a critical note. This quote is not intended for primary reference, but as a comparison in analyzing the meaning of sentences. The following hadith is the example: ${ }^{56}$

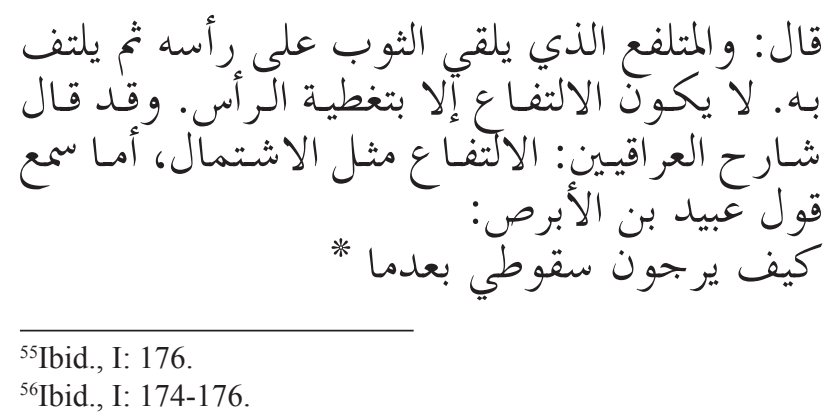




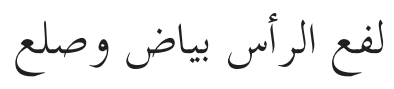

Meaning: 'Abd al-Malik bin Habîb said, "Almutalaffi' is a person who wears his clothes on his head and then covers it. Therefore, aliltifâ' cannot be accepted unless by covering the head. Shârih al-'Irâqiyyîn (a.k.a 'Ubaid bin Sallām) says that iltifâ' is like isytimâl (universal) as said by Ubaid bin al-Abras:

"How do they expect for my fall after my hair is covered with gray and I have become bald."

d) Explaining The Hadith Sentences With Arabic Jahiliyah

The poem written by 'Ubaid bin al-Abraș, Imru 'al-Qais and others is the example for this method. See the following poem (Syi'ir) by 'Ubaid bin al-Abraș: ${ }^{57}$

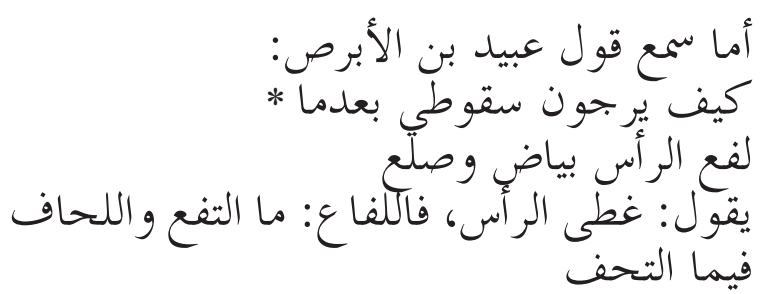

Meaning: As 'Ubaid bin al-Abras said:

"How do they expect for my fall after my hair is covered with gray and I have become bald." He said, "Cover the head". This means lifầ' is something which can cover by encircling, while lihâf is a thing which is covered."

e) Explaining The Hadith Sentences With The Definitions of Sentences Used by The Arabs

Explaining the Hadith sentences with the Arabic Jahiliyah syiir (poem) or the definition of the sentences used by the Arabs is considered the most representative method as it represents the habit of using Arabic in the community. See the following: ${ }^{58}$

${ }^{57}$ Ibid., I: 175-176.

${ }^{58}$ Ibid., I: 204.

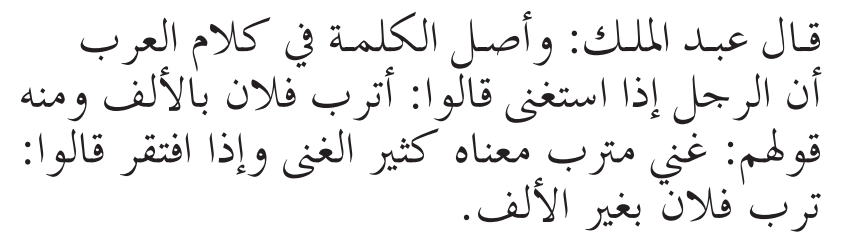

Meaning: 'Abd al-Malik bin Habîb said, "The origin of sentence in Arabic is that someone does not need to say 'Atraba fulan' with the letter alif or their words 'Ghinâ mutrib' which means a lot of wealth. If someone needs, they will say, 'Tariba Fulan' without the letter Alif."

In verifying sharh hadith, 'Abd al-Malik bin Habîb determines several factors as follow:

a) Factual and Historical Factors

The the word hujrah, for example, is interpreted as al-dâr, not min wasat buyut al-dâr as done by people in al-Andalus. ${ }^{59}$ In another hadith, khâtimah al-balât is marked by a white house in the al-Zaurâ' market in Medina. ${ }^{60}$

\section{b) Tradition Factor}

The word tanfasah (carpet), for instance, is not used to know time, but it is used to sit. The carpet is then forgotton. ${ }^{61}$ This traditional factor is also widely used in seeing the practices carried out by experts in Medina, such as delivering animals for sacrifice (qurban). ${ }^{62}$ 'Abd al-Malik bin Habîb criticizes the tradition of Irâqiyyûn (the Iraq people) which is often different from the tradition in Medina, where the hadith comes from. ${ }^{63}$

\section{c) Rationality and Empirical Factors}

The word safar is not interpreted as the month of safar, but as a stomach disease (dawâbb albaṭn). 'Abd al-Malik bin Habîb has examined several hadiths related to safar and all of them do

\footnotetext{
${ }^{59}$ Ibid., I: 171.

${ }^{60}$ Ibid., I: 184.

${ }^{61}$ Ibid., I: 179.

${ }^{62}$ Ibid., I: 336-337.

${ }^{63}$ Ibid., II: 195; 221-222.
} 
not show the month of safar. ${ }^{64}$ In his empirical factor the number of stars in the galaxy and four seasons in Arab is the example. ${ }^{65}$

\section{d) Locality Factor}

The locality refers to here is the locality of the al-Andalus region, in which geographically the flora, fauna and goods used are much different from the Arab community, such as the sindiyyah slippers $^{66}$, the sarhah tree which is not available in al-Andalus, ${ }^{67}$ the jazar (carrot) which is referred to as iștaflin in Shâm and isfinâriyyah (zanahoria, Spanish) in al-Andalus ${ }^{68}$, and the $q u f^{\prime} a h$ which is called as quffah mustatlah by the al-Andalus people. $^{69}$

\section{e) Theological Factors}

Such factor is influenced by the theological sects that develop in Medina and its surroundings, especially the $\mathrm{Mu}$ 'tazilah sect which is made the official state school of law by 'Abbâsiyyah government. As one of the followers of Mâlik, 'Abd al-Malik bin Habîb rejects the Qadariyyah ideology supported by Mu'tazilah, Abû Ḥanîfah (d. 150/767) and his followers are considered Murji'ah and Khawârij. ${ }^{70}$

\section{f) Political Factor}

This factor is used in understanding the status and position of the Umayyad government in the Islamic state and the infidels in al-Andalus. AlAndalus, for example, is considered as an area where kâfir dzimmî does not have to pay taxes if selling from one area to another while in alAndalus. ${ }^{71}$

Another example is that Sham is an area with many illnesses, ${ }^{72}$ the interpretation and reading of

\footnotetext{
${ }^{64}$ Ibid., II: 149.

${ }^{65}$ Ibid., I: 255-256.

${ }^{66}$ Ibid., I: 320.

${ }^{67}$ Ibid., I: 342-343.

${ }^{68}$ Ibid., I: 372.

${ }^{69}$ Ibid., II: 140.

${ }^{70}$ Ibid., II: 74; 170-172.

${ }^{71}$ Ibid., I: 280.

${ }^{72}$ Ibid., II: 111-112.
}

the ulama 'Irâq which contradicts to $a l-j i d d,{ }^{73}$ Irâq which is full of misleading jinn and diseases such as Abu Hanifa and the appearance of defamation, ${ }^{74}$ the justification for the Mu'âwiyah Caliphate supported by A'ishah, ${ }^{75}$ and the expert of the Irâq who is despotic to al-Hajjâj. ${ }^{76}$ Some of the stigmas that appear in 'Abd al-Malik bin Habîb's comments are political. The reason is that the Syam region is the place where imam al-Auzâ' $\hat{\imath}$ who is considered to receive reconciliation from the 'Abbâsiyyah dynasty rulers, the main rival of the Umayyad dynasty lived. ${ }^{77}$ In addition, Irâq is also the base of Hanafi School as the official school in the Abbâsiyyah dynasty. ${ }^{78}$

Legitimacy or justification over the Mu'âwiyah Caliphate is also considered political support for the existence of the Umayyad dynasty in alAndalus. In addition, 'Abd al-Malik bin Habîb has called for the obligation to unite Muslims for all religions, ${ }^{79}$ and Muslims who are not punishable by qiṣâs when they kill kāfir dzimmî. ${ }^{80}$ This is related to the consolidation of power and government reinforcement in al-Andalus.

\section{The Power Relation of Knowledge in Tafsir Gharîb al-Muwațța'}

Referring to some of the above descriptions, the epistemology of sharh hadith in the book written by 'Abd al-Malik bin Habîb is more directed to the theological, political and social problems that existed in his time. This is due to several things; first, the practical interest in understanding the hadith for the al-Andalus

\footnotetext{
${ }^{73}$ Ibid., II: 113.

${ }^{74}$ Ibid., II: 160-161.

${ }^{75}$ Ibid., II: 205-206.

${ }^{76}$ Ibid., II: 208.

${ }^{77}$ Muhammad Akmaluddin, "The Origin of Fiqh Schools in alAndalus: From Qairawan to Medina," International E-Journal of Advances in Social Sciences 3, no. 9 (2017): 880-887; W. Montgomery Watt and Pierre Cachia, A History of Islamic Spain (Edinburgh: Edinburgh University Press, 1977), 64.

${ }^{78}$ al-Maqdisî, Ahsan al-Taqâsîm fî Ma 'rifah al-Aqâlîm, 236-237; 'Alî bin Ahmad Ibn Ḥazm al-Andalusî, Rasâ'il Ibn Hazm, II, ed. Iḥsân 'Abbâs (Beirut: Al-Mu'assasah al-'Arabiyyah li al-Dirâsât wa al-Nasyr, 1987), 229.

${ }^{79}$ al-Sulamî, Tafsîr Gharîb al-Muwatta', II: 216-217.

${ }^{80}$ Ibid., II: 221.
} 
people. Hadith is something which is not so popular, let alone understanding the sentences that are unfamiliar and rarely heard by them. To this end, he has done a lot of descriptive analysis to define a sentence, flora, fauna and places and goods used by the Arab society; second, political interests for power and Islam reinforcement in al-Andalus. This is because al-Andalus is a multiethnic region including the Arabs, Barbarians, Norman (Vikings), patrons (mawâlî), SpanishIslamic descendants (muwalladûn), Jews, Aryan descendants and others. ${ }^{81}$ The fore, the unity of all schools and a clear ideological foundation is needed to establish a conducive and stable government and religion in al-Andalus.

The muhadditsûn (hadith experts) focus on the study of matn (wording) hadith more than the one of isnâd considering it is more necessary to deliver and accept hadith to or from the al-Andalus people. The study of isnâd has not actually got more attention compared to what has happened Masyriq since the first time, which was undertaken by Yahyâ bin Ma'în, al-Bukhârî, Ibn Hanbal and others. The style and model of the hadith narrated by muhadditsûn is not far from the Mâlik School. This happens due to the Mâlik's power and hegemony in al-Andalus. In this method, they receive and narrate hadiths containing and reinforcing Mâlik's opinion $\left(r a^{\prime} y\right) .{ }^{82}$ In the second to the third century AH particularly, the Mâlikî School itself was in the stage of introduction and formation to the society. ${ }^{83}$

The influencing factor is the Islam reinforcement on one school and a strong line in al-Andalus, fighting against defamation and ignorance in the society, and reinforcing the basis of religion and the state. Therefore, this episteme follows what has been built by the fuqaha' (legal scholars) and the previous qudâh (judges) in order to achieve the objectives of Islam and state reinforcement. The authority or

\footnotetext{
${ }^{81}$ Dwedâr, al-Mujtama ' al-Andalusî fí al- 'Așr al-Umawî, 14-66. ${ }^{82}$ Christopher Melchert, The Formation of the Sunni Schools of Law, 9th-10th Centuries C.E, Studies in Islamic law and Society v. 4 (Leiden: New York: Brill, 1997), 159.

${ }^{83}$ Muhammad Khalid Masud, "A History of Islamic Law in Spain: An Overview," Islamic Studies 30, no. 1/2 (1991): 7-35.
}

power of qudâh developed at the time. Thus, each person might not narrate, study, eat, or do anything except under the provisions of qudâh in al-Andalus. ${ }^{84}$ This is in line with what Aṣbagh bin Khalîl did, forbidding Qâsim ibn Așbagh to narrate from Baqî bin Makhlad and follow the Shâfi'î School practices, in which many have contradicted even though the two were once neighbors. This is because Baqî did not embrace any books other than the Mâlik, while Aṣbagh was a member of qudâh who was devoted to the Mâlik School.

The power and knowledge relation, such as the epistemology of the sharh hadith above, is based on Michel Foucault's thesis confirming that the study of subject cannot be separated from power. Power is a prerequisite to process the knowledge production and an important aspect of all patterns of social relations. ${ }^{85}$ According to him, power is the dominance between subjects and objects in which the power is mechanical, not property. The concept of power presented by Foucault is different from the traditional view which says that power is repressive. The power according to him is actually positive and productive. Such power comes to different layers of society, so that it is rooted in various social relationships by any individual in the existing knowledge relations and institutions. ${ }^{86}$ This is certainly different from the concept of traditional power by Freud, Hegel and Marxist who consider it as property and its authoritative nature. ${ }^{87}$

\footnotetext{
${ }^{84} \mathrm{See}$, for example, the influence of hadith study on politics in L.A. Majid and N. Kurt, "Bahr Al-Madhi: Significant Hadith Text Sciences for Malay Muslims as a Tool for Political Teaching during Twentieh Century," Mediterranean Journal of Social Sciences 5, no. 20 (2014): 2249-2254.

${ }^{85}$ Michel Foucault, Power/Knowledge: Selected Interviews and Other Writings, 1972-1977, ed. Colin Gordon, trans. Colin Gordon et. al. (Pantheon Books, 1980), 134-145; Michel Foucault, "Intellectuals and Power," in Language, CounterMemory, Practice: Selected Essays and Interviews, ed. D. F. Bouchard (Ithaca, N.Y.: Cornell University Press, 1972), 205217; Madan Sarup, Posstrukturalisme Dan Posmodernisme: Sebuah Pengantar Kritis, trans. M.A. Hidayat (Yogyakarta: Penerbit Jendela, 2003), 149.

${ }^{86}$ Michel Foucault, The Archaeology of Knowledge, 2nd ed., Routledge Classics (Routledge, 2002), 136.

${ }^{87}$ Michel Foucault, The History of Sexuality, Vol. 1: An Introduction (Random House, 1978), 94-95; Michel Foucault, Ingin Tahu Sejarah Seksualitas, trans. R.S. Hidayat (Jakarta:
} 
Thus, the power and knowledge relation in the epistemology of sharh hadith is productive, producing practical and principle-based knowledge for the people in al-Andalus. In terms of practicality, the epistemology of sharh hadith in al-Andalus emphasizes social or socio-epistemological epistemology, which is knowledge of character or social character attempting to restore the realm of thinking and knowledge for the open-minded and dynamic human interests. Here, the socio-epistemology introduces social rationality or communication, which is not transcendent and keeps away from human struggles. ${ }^{88}$

This socio-epistemology is used for practical interest for society as the sharh hadith sees the reality and locality in al-Andalus. Similarly, the figure before 'Abd al-Malik bin Habîb such as Yahyâ bin Yahyâ al-Laitsî has issued a fatwa demanding 'Abd al-Raḥmân bin al-Hakam to fast for two months in a row when doing wiq $\hat{a}^{`}$ based on his social facts. ${ }^{89}$ The knowledge of sharh hadith is not only addressed to the fuqaha', but for the public in general.

\section{Conclusion}

The study of hadith in classical and modern literature examines the quality of hadith, both in terms of isnad (chains of narrators) and matn (wording). It actually contains many study repetition. In addition, it also takes place in the area of the Arabian Peninsula or the Masyriq region only. In turn, it has finally become a centric study of hadith in the Middle East, which does not learn the knowledge of hadith in peripheral regions. In fact, there are also many studies of hadith that need to be examined in many

\footnotetext{
Yayasan O b or Indonesia, 2008); Haryatmoko, "Kekuasaan Melahirka n Anti-Kekuasaan," Basis 51, no. 1-2 (2002): 8-21; Larry Shiner, "Reading Foucault: Anti-Method and the Genealogy of Power-Knowledge," History and Theory 21, no. 3 (1982): 382-398.

${ }^{88}$ Aholiab Watloly, Sosio-Epistemologi: Membangun Pengetahuan Berwatak Sosial (Yogyakarta: Kanisius, 2016), 3.

${ }^{89}$ al-Maqqarî, Nafh al-Tîb min Ghusn al-Andalus al-Rațîb wa Dzikr Wazîrihâ Lisân al-Dîn Bin al-Khatîib, II: 10-11.
}

peripheral areas and certainly will provide a more varied colour of study, as in the study of hadith in al-Andalus, India, and even the Archipelago.

The knowledge of sharh hadith in alAndalus in the second to the third century AH was dominated and hegemonized by the Mâlikî School. Such dominance and hegemony was a form of the power-knowledge relation of hadith in al-Andalus at that time. Such relation then caused the sentiments of the Umayyad dynasty, regional fanaticism and the attack of knowledge in Masyriq. The Umayyad rulers along with the fuqaha even censored and prohibited various books and knowledge besides Muwațta' Mâlik and the Mâlik School. With the existence of these factors, muhadditsûn in al-Andalus then tried to become independent from various studies of sharh hadith in Masyriq. They eventually established a new 'school' to understand the hadith which was in accordance with the situation and conditions in al-Andalus.

Under the new school, they attempted various efforts to translate the hadith into the locality of culture, language and level of knowledge. Despite the hegemony and dominance of al-Andalus, the Mâlik School has basically laid down a systematic foundation of knowledge with the written sharh hadith. Hegemony, domination and power-knowledge relation in al-Andalus are not repressive, but provide new products for the knowledge of hadith in the Islamic world.

\section{References}

Akmaluddin, Muhammad. "Developments of Hadîth Riwâya in al-Andalus (2nd - 3rd Centuries of Hijriyya)." Ulumuna 21, no. 2 (2017): 228-252.

- "Silsilah Riwâyah al-Ahâdîts Fî alAndalus: Di râsah Jîniyâlûjiyyah Li Tațawwur Riwâyah al-Aḥ̂adîts Fî al-Qarn al-Tsânî Wa al-Tsâlits Al-Hijrî." M.A., 
UIN Walisongo, 2015.

"The Origin of Fiqh Schools in alAndalus: From Qairawan to Medina." International E-Journal of Advances in Social Sciences 3, no. 9 (2017): 880-887.

Amîn, Aḥmad. Zuhr Al-Islâm. Kairo: Mu'assasah Hindâwî li al-Ta'lîm wa al-Tsaqâfah, 2012.

al-Andalusî, 'Alî bin Aḥmad Ibn Hazm. Rasâ'il Ibn Hazm. Edited by Iḥân 'Abbâs. Beirut: Al-Mu'assasah al-'Arabiyyah li al-Dirâsât wa al-Nasyr, 1987.

al-Andalusî, Șâ‘îd bin Ạ̣mad. Kitâb Ṭabaqât Al-Umam. Beirut: al-Maktabah alKâtsûlîkiyyah li al-Abâ' al-Yasû'iyyîn, 1912.

al-Aṣbâhî, Mâlik bin Anas. Muwațậ' Al-Imâm Mâlik. Edited by Muḥammad Fu'âd 'Abd al-Bâqî. Beirut: Dâr Ihyâ’ al-Turâts al'Arabî, 1985.

Aswad, Muhammad 'Abd al-Razzâq. Al-Ittijâhât al-Mu'âșirah Fî Dirâsah al-Sunnah alNabawiyyah Fi Miṣr Wa Bilâd Syâm. Damaskus: Dâr al-Kalim al-Ṭayyib, 2000.

al-Baidâwî, Abû Ya'lâ. Al-Ta 'lîqât Al-Mustaẓrifah 'alâ Al-Risâlah Al-Mustatrafah. Beirut: Dâr al-Kutub al-'Ilmiyyah, 2011.

al-Barr, Yûsuf bin 'Abd Allâh Ibn 'Abd. Al-Tamhîd Li Mâ Fî al-Muwatța' Min al-Ma 'ânî Wa al-Asânîd. Maroko: Wizârah 'Umûm alAuqâf wa al-Syu'ûn al-Islâmiyyah, 1387.

al-Bukhtî, Jamâl 'Ilâl. "Al-Madrasah al'Aqdiyyah al-Ûlâ Bi al-Andalus Baina Ahl al-Fiqh Wa Ahl al-Hadîts.” 161-205. Maroko: al-Râbițah al-Muhammadiyyah li al-'Ulamâ,' 2011.

Dwedâr, Husain Yûsuf. Al-Mujtama 'al-Andalusî Fîal- 'Așr al-Umawî. Kairo: Maṭba'ah alḤusain al-Islâmiyyah, 1994.

Fierro, Maribel. "Accusations of 'Zandaqa' in
al-Andalus." Quaderni di Studi Arabi 5/6 (1987): 251-258.

. "Local and Global in Hadîth Literature: The Case of Al-Andalus." In The Transmission and Dynamics of the Textual Sources of Islam: Essays in Honour of Harald Motzki, edited by Nicolet Boekhoff-van der Voort, Kees Versteegh, and Joas Wagemakers, 63-88. London: Brill, 2011.

- "The Introduction of Hadîth in alAndalus (2nd/8th-3rd/9th Centuries)." Der Islam 66 (1989): 68-93.

Foucault, Michel. Ingin Tahu Sejarah Seksualitas. Translated by R.S. Hidayat. Jakarta: Yayasan Obor Indonesia, 2008.

. "Intellectuals and Power." In Language, Counter-Memory, Practice: Selected Essays and Interviews, edited by D. F. Bouchard, 205-217. Ithaca, N.Y.: Cornell University Press, 1972.

. Power/Knowledge: Selected Interviews and Other Writings, 1972-1977. Edited by Colin Gordon. Translated by Colin Gordon, Leo Marshall, John Mepham, and Kate Soper. Pantheon Books, 1980.

. The Archaeology of Knowledge. 2nd ed. Routledge Classics. Routledge, 2002.

___ The History of Sexuality, Vol. 1: An Introduction. Translated by Robert Hurley. Random House, 1978.

al-Ghalbazûrî, Taufîq. "Taṭawwur 'Ilm al-Hadîts Bi al-Maghrib Wa al-Andalus Ilâ al-'Așr al-Hâdụir Wa Juhûd al-'Allâmah alMuhaddits al-Duktûr Ibrâhîm Bin Șiddîq al-Ghumârî Fî Khidmatihî.” 381-415. Maroko: al-Râbițah al-Muhammadiyyah li al-'Ulamâ,' 2011.

Haryatmoko. "Kekuasaan Melahirkan AntiKekuasaan.” Basis 51, no. 1-2 (2002): 8-21. 
Hendrickson, Jocelyn. "Is al-Andalus Different?

Continuity as Contested, Constructed, and Performed Across Three Mâlikî Fatwâs." Islamic Law and Society 20, no. 4 (2013): 371-424.

Husain, Karîm 'Ajîl. “Al-Tamhîd Li al-Tadwîn al-Târikhî Fî al-Andalus Hattâ Nihâyah alQarn al-Tsânî al-Hijrî.” Majallah Jâmi 'ah Tikrît li al- 'Ulûm al-Insâniyyah 14, no. 11 (2007): 185-226.

Ibn al-Faraḍ̂, 'Abd Allâh bin Muhammad. Târîkh 'Ulamâ' al-Andalus. Edited by Basysyâr 'Awwâd Ma'rûf. Tunis: Dâr al-Gharb alIslâmî, 2008.

al-Isybîlî, al-Fatḥ bin Muḥammad al-Qaisî. Matmah al-Anfus Wa Masraḥ alTa'annus Fi Milh Ahl al-Andalus. Edited by Muhammad 'Alî Syawâbikah. Dâr 'Ammâr: Mu'assasah al-Risâlah, 1983.

al-Jâbirî, Muḥammad 'Âbid. Isykâliyyât al-Fikr al- 'Arabî al-Mu'Âșir. Beirut: Markaz Dirâsât al-Waḥdah al-'Arabiyyah, 1990.

al-Kattânî, Muhammad bin Ja'far. Al-Risâlah al-Mustațafah Li Bayân Masyhûr Kutub al-Sunnah al-Musyarrafah. Beirut: Dâr al-Kutub al-'Ilmiyyah, 2011.

Khalîfah, Mușțafâ bin 'Abd Allâh Hâjjîi. Kasyf alZunûn 'an Asâmî al-Kutub Wa al-Funûn. Baghdad: Maktabah al-Mutsannâ, 1941.

Majid, L.A., and N. Kurt. "Bahr Al-Madhi: Significant Hadith Text Sciences for Malay Muslims as a Tool for Political Teaching during Twentieh Century." Mediterranean Journal of Social Sciences 5, no. 20 (2014): 2249-2254.

al-Mâlikî, Muhammad bin 'Alî bin 'Umar al-Tamîmî al-Mâzirî. Al-Mu 'Lim Bi Fawâ'Id Muslim. Edited by M. al-Syâdzâlî al-Nîfar. Tunis: alDâr al-Tûnisiyyah li an-Nasyr, 1988.

al-Maqdisî, Muḥammad bin Aḥmad. Aḥsan alTaqâsîm Fî̀ Ma'rifah al-Aqâlîm. Kairo:
Matba'ah al-Madbûlî, 1991.

al-Maqqarî, Aḥmad bin Muḥammad. Naf̣̆ al-Ṭ̂ib Min Ghusn al-Andalus al-Ratîb Wa Dzikr Wazîrihâ Lisân al-Dîn Bin al-Khațîb. Edited by Ihsân ‘Abbâs. Beirut: Dâr Șâdir, 1997.

Marín-Guzmán, Roberto. "La Rebelión Muladí En al-Andalus y Los Inicios de La Sublevación de 'Umar Ibn Hafsun En Las Épocas de Muhammad I y al-Mundhir (880-888)." Estudios de Asia y Africa 33, no. 2 (106) (1998): 233-284.

"Social and Ethnic Tensions in alAndalus: Cases of Ishbîliyah (Sevilla) 276/889 -302/914 and Ilbîrah (Elvira) 276/889 - 284/897 — The Role of 'Umar Ibn Hafṣûn." Islamic Studies 32, no. 3 (1993): 279-318.

. "The End of the Revolt of 'Umar Ibn Hafșûn in al-Andalus: The Period of 'Abd al-Raḥmân III (912-28).” Islamic Studies 34, no. 2 (1995): 153-205.

. "The revolt of 'Umar Ibn Hafsun in al-Andalus: A Challenge to the Structure of the State (880-928)." Ph.D., 1994.

Masud, Muhammad Khalid. "A History of Islamic Law in Spain: An Overview." Islamic Studies 30, no. 1/2 (1991): 7-35.

Melchert, Christopher. The Formation of the Sunni Schools of Law, 9th-10th Centuries C.E. Studies in Islamic Law and Society v. 4. Leiden: New York: Brill, 1997.

Mustansyir, Rizal, and Misnal Munir. Filsafat Ilmu. Yogyakarta: Pustaka Pelajar, 2015.

Safran, Janina M. "Identity and Differentiation in Ninth-Century al-Andalus." Speculum 76, no. 3 (2001): 573-598.

Sarup, Madan. Posstrukturalisme Dan Posmodernisme: Sebuah Pengantar 
Kritis. Translated by M.A. Hidayat. Yogyakarta: Penerbit Jendela, 2003.

Shiner, Larry. "Reading Foucault: AntiMethod and the Genealogy of PowerKnowledge." History and Theory 21, no. 3 (1982): 382-398.

al-Sulamî, 'Abd al-Malik bin Ḥabîb bin Sulaimân. "Al-Muqaddimah." In Tafsîr Gharîb alMuwatta', edited by 'Abd al-Raḥmân bin Sulaimân al-'Utsaimîn, 9-167. Riyadh: Maktabah al-‘Abîkân, 2001.

- Tafsîr Gharîb al-Muwatta'. Edited by 'Abd al-Raḥmân bin Sulaimân al-'Utsaimîn. Riyadh: Maktabah al-'Abîkân, 2001.

al-Syahrazûrî, 'Utsmân bin 'Abd al-Raḥmân Ibn Șalâh. Waṣl Balâghât Al-Muwațta'. Edited by 'Abd al-Fattâh Abû Ghuddah. Aleppo: al-Mațba'ah al-'Ilmiyyah, n.d.
Watloly, Aholiab. Sosio-Epistemologi: Membangun Pengetahuan Berwatak Sosial. Yogyakarta: Kanisius, 2016.

Watt, W. Montgomery, and Pierre Cachia. A History of Islamic Spain. Edinburgh: Edinburgh University Press, 1977.

al-Yaḥ̣ubî, Iyậ̣ bin Mûsâ. Al-Ilmâ' Ilâ Ma 'rifah Usûl al-Riwâyah Wa Taqyîd al-Samấ. Edited by al-Sayyid A. Șaqar. Kairo: Dâr al-Turâts, 1970.

al-Dzahabî, Muḥammad bin Aḥmad. Siyar A'lâm al-Nubalâ'. Edited by Syu'aib alArnâ'ûṭ. Beirut: Mu'assasah al-Risâlah, 1985.

- Târîkh al-Islâm Wa Wafayât al-Masyâhîr Waal-A'Lâm. Edited by Basysyâr 'Awwâd Ma'rûf. Tunis: Dâr al-Gharb al-Islâmî, 2003. 